\title{
Impact of Delay on Cost Overrun in Construction Projects in
}

Algeria

\author{
Salhi Roumeissa \\ PhD candidate, Dept. of Civil Engineering, \\ University 20 Août 1955 SKIKDA, Algeria
}

\begin{abstract}
Project success is the ultimate goal of the various project stackeholders (Salhi.R 2018). Asuccessful project means that the project is completed on time, within the agreed budget and according to the contract specifications. Delay is one of the most reccuring problems in construction project in Algeria, and it is considered as the main cause of cost overrun, time overrun, disput and claims.The objective of this paper is to mesure the impact of schedule delay on cost overrun, using the simple linear regression method and the coefficient of correlation. The proposed model can be used by practitioners as predictive mesure to address possible cost overrun.
\end{abstract}

Keywords: delay, project construction, impact of delay, cost overrun, Algeria

\section{Introduction}

"Project success is the ultimate goal of the various project stakholders" (Salhi et al 2018). And according to chan and Kumarswamy 1994, "timely delivery of projects within budget and to the level of quality is an index of successful project delivery".

"Delay in construction project is a problem facing by the whole world" (Sambasivan and soon 2007), this delay has significant effects on construction project, among these effects cost overruns, "when project are delayed they are either accelerated or have their duration extended beyong the scheduled compelation date. These are not without some cost consequence."(Aibinu and Jagboro 2002), "delays are almost always accompanied by cost overruns."(Gajare et al 2014), "due to delay the construction firms have to bear more cost labor, equipement and tools. (Sun and Ming 2009).

In Algeria, construction delays has become endemic, "62\% of projects have experienced timeouts."(Salhi et al 2018), the objective of this paper is to mesure the impact of delays on cost overruns in Algerian construction project. 


\section{Research methodology}

Data from 11 public construction projects in the region of Constantine in Algeria has been collected, in order to empirically investigate the effect of delay on cost overrun in Algerian construction project. These projects were classified into 2 categories according to their sector: administrative buildings and economic infrastructures and education sector. The informations obtained from the 11 selected projects includes: planned duration (PD), actual duration (AD), planned cost (PC), actual cost (AC). In order to examine the effect of delay on cost overrun we have introduced 2 variables: cost overrun (equation 1) and time overrun (equation 2), and then the effect of time overrun on cost overrun was investigated using the simple linear regression.

Regression equation,calculated Fisher statistic, and the level of significance of association beteween the 2 variables(Time overrun and Cost overrun) were computed at the level of significance of $10 \%$.

Cost overrun (CO) $=$ Actual Cost (AC) - Planned Cost (PC)

Time overrun (TO) = Actual Duration (AD) - Planned Duration (PD).

\section{Discussion and results}

\section{Descriptive statistics}

Data obtained from the 11 selected projects (AD, PD, AC, PC, TO, CO) were presented in table 1 , and the descriptive statistics from these projects were summarized in table 2.

Planned and actual duration: the mean of actual duration for the 11 selected projects was 1147,64 days, with a standard deviation of 687,905 days, while the planned duration was 284, 09 in mean and 110,324 in standard deviation. Regarding the project sector, the findings were as follow: for the category of administrative buildings and economic infrastructures the mean of planned duration varied from 316,20 days to 1674 days.

However, the mean of planned and actual duration for the category of education was respectively: 257,33days and 709 days. From these results we can notice that the actual duration for each project varies considerably from the planned duration.

These results were similar for the findings of (Salhi et al 2018), "there is a large difference between the mean of planned and actual duration and a high value of standard deviation", and (Al-momani 2000), "the time required to complet construction of pulic projects is frequently gretear than the time specified in the contract."

Planned and actual cost: the mean of actual cost for the 11 selected projects was $416890,27 * 10^{3} \mathrm{DA}$, with a hight standard deviation of $359648,218^{*} 10^{3} \mathrm{DA}$, while the planned cost for the same projects was $155034,27^{*} 103 \mathrm{DA}$ in mean and 94241, $058^{*} 10^{3} \mathrm{DA}$ in standard deviation. 
Concerning the sector of administrative buildings and economic infrastructures the mean of planned cost varied from $69200^{*} 10^{3}$ DA to an actual cost of $129680^{*} 10^{3} \mathrm{DA}$. Further, for the projects of education sector the mean of planned and actual cost was respectively: $226562,83^{*} 10^{3}$ and $656232,17^{*} 10^{3} \mathrm{DA}$.

From these results we can notice that there is a large difference between the mean of actual and planned cost and a high values of standard deviation, thus we can say that the cost required to complete contruction project is almost always greater than the cost specified in the contract, and this can be explained by the augmentation rate of time overrun, according to (Gbahabo and Ajuwon 2017) who identified schedule overruns as the primary cause of cost overruns", and (Gajare et al 2014)who affirms that "delays are almost always accompanied by cost overruns."

Table 1: Time and cost overruns

\begin{tabular}{|c|c|c|c|c|c|c|c|}
\hline Sector & $\begin{array}{l}\text { Proje } \\
\text { ct }\end{array}$ & $\begin{array}{l}\text { PD } \\
\text { (days } \\
\text { ) }\end{array}$ & $\begin{array}{l}\mathrm{AD} \\
\text { (days) }\end{array}$ & $\begin{array}{l}\mathrm{PC}^{*} 10^{3} \\
(\mathrm{DA})\end{array}$ & $\begin{array}{l}\mathrm{AC} * 10^{3} \\
(\mathrm{DA})\end{array}$ & $\begin{array}{l}\text { T0 } \\
\text { (days) }\end{array}$ & $\begin{array}{l}\text { CO } \\
\text { (days) }\end{array}$ \\
\hline \multirow{5}{*}{$\begin{array}{l}\text { administrat } \\
\text { ive } \\
\text { buildings } \\
\text { and } \\
\text { economic } \\
\text { infrastruct } \\
\text { ures }\end{array}$} & 1 & 182 & 699 & 38000 & 79400 & 517 & 41400 \\
\hline & 2 & 365 & 1461 & 38000 & 98000 & 1096 & 60000 \\
\hline & 3 & 152 & 1930 & 40000 & 107000 & 1778 & 67000 \\
\hline & 4 & 426 & 1784 & 80000 & 130000 & 1358 & 50000 \\
\hline & 5 & 456 & 2496 & 150000 & 234000 & 2040 & 84000 \\
\hline \multirow[t]{6}{*}{ Education } & 6 & 152 & 1188 & 155777 & $\begin{array}{l}124219 \\
6\end{array}$ & 1036 & $\begin{array}{l}10864 \\
19\end{array}$ \\
\hline & 7 & 207 & 253 & 189400 & 410000 & 46 & $\begin{array}{l}22060 \\
0\end{array}$ \\
\hline & 8 & 273 & 731 & 228700 & 466500 & 458 & $\begin{array}{l}23780 \\
0\end{array}$ \\
\hline & 9 & 334 & 731 & 228700 & 466500 & 397 & $\begin{array}{l}23780 \\
0 \\
\end{array}$ \\
\hline & 10 & 213 & 711 & 273000 & 525079 & 498 & $\begin{array}{l}25207 \\
9\end{array}$ \\
\hline & 11 & 365 & 640 & 283800 & 827118 & 275 & $\begin{array}{l}25207 \\
9\end{array}$ \\
\hline
\end{tabular}

*Planned duration (PD), actual duration (AD), planned cost (PC), actual cost (AC), time overrun (TO), cost overrun (CO), Algerian dinar (DA)

Table 2: Descriptive statistics

\begin{tabular}{|l|l|l|l|l|l|l|}
\hline \multicolumn{2}{|c|}{} & Duration & Cost \\
\hline Sector & \multicolumn{2}{|l|}{$\begin{array}{l}\text { Number } \\
\text { of project }\end{array}$} & $\begin{array}{l}\text { Planned(P } \\
\text { D) }\end{array}$ & $\begin{array}{l}\text { Actual(A } \\
\text { D) }\end{array}$ & $\begin{array}{l}\text { Planned*10 } \\
\text { PC) }\end{array}$ & $\begin{array}{l}\text { Actual*10 } \\
\text { AC) }\end{array}$ \\
\hline $\begin{array}{l}\text { Administrat } \\
\text { ive }\end{array}$ & 5 & Min & 152 & 699 & 38000 & 79400 \\
\cline { 2 - 7 } & & Max & 456 & 2496 & 150000 & 234000 \\
\hline
\end{tabular}




\begin{tabular}{|c|c|c|c|c|c|c|}
\hline \multirow{2}{*}{$\begin{array}{l}\text { buildings } \\
\text { and } \\
\text { economic } \\
\text { infrastructu } \\
\text { res }\end{array}$} & & $\begin{array}{l}\text { Mea } \\
\mathrm{n}\end{array}$ & 316,20 & 1674 & 69200 & 129680 \\
\hline & & SD & 140,493 & 661,308 & 48592,180 & 61091,833 \\
\hline \multirow[t]{4}{*}{ Education } & \multirow[t]{4}{*}{6} & Min & 152 & 253 & 155777 & 410000 \\
\hline & & Max & 365 & 1188 & 283800 & 1242196 \\
\hline & & $\begin{array}{l}\text { Mea } \\
\mathrm{n}\end{array}$ & 257,33 & 709,00 & 226562,83 & 656232,17 \\
\hline & & SD & 81,620 & 297,694 & 48648,431 & 323228,589 \\
\hline \multirow[t]{4}{*}{ All } & \multirow{4}{*}{$\begin{array}{l}1 \\
1\end{array}$} & Min & 152 & 253 & 38000 & 79400 \\
\hline & & Max & 456 & 2496 & 283800 & 1242196 \\
\hline & & $\begin{array}{l}\text { Mea } \\
\mathrm{n}\end{array}$ & 284,09 & 1147,64 & 155034,27 & 416890,27 \\
\hline & & SD & 110,324 & 687,905 & 94241,058 & 359648,218 \\
\hline
\end{tabular}

\section{Linear regression}

The simple linear regression was used to describe the relashionship between the identified variables: cost overrun and time overrun. The regression equation, coefficient of determination, and the fisher values obtained from the regression analysis of cost overrun on time overrun are shown in tables $(3,4,5,6,7,8)$. The equations developed to mesure the cost overrun based on the time overrun are as follows:

For the projects of administrative buildings and economic infrastructure:

$Y=24,66 X+27000$

For the projects of education sector:

$Y=828,8 \mathrm{X}+55337$

Were:

$\mathbf{Y}$ the dependent variable represents "cost overrun" (CO), and $\mathbf{X}$ the independent variable represents "time overrun" (TO)

The coefficients of determination $\mathrm{R}^{2}$ were found to be 0,806 and 0,628 for the projects of administrative buildings and economic infrastructure, and education sector respectively. These implies that $80,6 \%$ and $62,8 \%$ of the variation in cost overrun of the respective projects categories can be explained by time overrun(time overrun explain a high percent of cost overrun).

The regression coefficients of correlation for the projects of administrative buildings and economic infrastructures, and the projects of education sector were respectively 0,898 and 0,793 . These indicate that the distrinution of time overrun mirrors the cost overrun with high degree of accuracy and ensure that there is a strong relationship between the 2 variables. 
Also, the calculated fisher statistic (for the administrative buildings and the economic infrastructures) was

$F(1,3)=12,430$ with $p$-value of $0,039<0,05$; hence, the model is significant at the level of $95 \%$. However, the calculated fisher (for the project of education sector) was $F(1,4)=6,758$ (with p-value $=0,6<0,10$ ); so, the model is significant at the level of $90 \%$.

Based on all this foregoing, we can say that there is a positive impact of delays on cost overrun and that the two proposed models were appropriate for prediction of cost overrun based on time overrun.

Table 3: Model summary (Administrative buildings and economic infrastructures)

\begin{tabular}{|c|c|c|c|c|c|c|c|c|c|}
\hline \multicolumn{10}{|c|}{ Model Summarya, c } \\
\hline \multirow{2}{*}{$\begin{array}{l}\text { Mo } \\
\text { del }\end{array}$} & \multirow[t]{2}{*}{$\mathrm{R}$} & \multirow{2}{*}{$\begin{array}{l}\mathrm{R} \\
\mathrm{Squ} \\
\text { are }\end{array}$} & \multirow{2}{*}{$\begin{array}{l}\text { Adjus } \\
\text { ted R } \\
\text { Squar } \\
\text { e }\end{array}$} & \multirow{2}{*}{$\begin{array}{l}\text { Std. Error } \\
\text { of the } \\
\text { Estimate }\end{array}$} & \multicolumn{5}{|c|}{ Change Statistics } \\
\hline & & & & & $\begin{array}{l}\text { R } \\
\text { Squar } \\
\text { e } \\
\text { Chang } \\
\text { e }\end{array}$ & $\begin{array}{l}\text { F } \\
\text { Chang } \\
\text { e }\end{array}$ & $\begin{array}{l}\text { df } \\
1\end{array}$ & $\begin{array}{l}\mathrm{df} \\
2\end{array}$ & $\begin{array}{l}\text { Sig. F } \\
\text { Chan } \\
\text { ge }\end{array}$ \\
\hline 1 & $\begin{array}{l}0,89 \\
8 b\end{array}$ & $\begin{array}{l}0,8 \\
06\end{array}$ & 0,741 & $\begin{array}{l}8326,532 \\
98\end{array}$ & 0,806 & $\begin{array}{l}12,43 \\
0\end{array}$ & 1 & 3 & 0,039 \\
\hline \multicolumn{10}{|c|}{$\begin{array}{l}\text { Sector = Administrative buildings and economic infrastructures. } \\
\text { Predictors: (Constant), TIME OVERRUN } \\
\text { Dependent variable : COSTOVERRUN }\end{array}$} \\
\hline
\end{tabular}

Table 4: ANOVA ((Administrative buildings and economic infrastructures)

\begin{tabular}{|c|c|c|c|c|c|c|}
\hline \multicolumn{7}{|c|}{ ANOVA $^{\mathrm{a}, \mathrm{b}}$} \\
\hline \multicolumn{2}{|c|}{ Model } & Sum of Squares & $\mathrm{df}$ & Mean Square & $\mathrm{F}$ & Sig. \\
\hline \multirow[t]{3}{*}{1} & Regression & $\begin{array}{l}861814545,37 \\
6\end{array}$ & 1 & $\begin{array}{l}861814545,37 \\
6\end{array}$ & \multirow[t]{3}{*}{12,430} & \multirow[t]{3}{*}{$0,039 \mathrm{c}$} \\
\hline & Residual & $\begin{array}{l}207993454,62 \\
4\end{array}$ & 3 & 69331151,541 & & \\
\hline & Total & $\begin{array}{l}1069808000,0 \\
00\end{array}$ & 4 & & & \\
\hline \multicolumn{7}{|c|}{ Sector = Administrative buildings and economic infrastructures. } \\
\hline \multicolumn{7}{|c|}{ Dependent Variable: COST OVERRUN } \\
\hline \multicolumn{7}{|c|}{ Predictors: (Constant), TIME OVERRUN } \\
\hline
\end{tabular}


Table 5: the coefficients of the line of regression (Administrative buildings and economic infrastructures)

\begin{tabular}{|c|c|c|c|c|c|c|}
\hline \multicolumn{7}{|c|}{ Coefficientsa,b } \\
\hline \multirow{2}{*}{\multicolumn{2}{|c|}{ Model }} & \multicolumn{2}{|c|}{$\begin{array}{l}\text { Unstandardized } \\
\text { Coefficients }\end{array}$} & \multirow{2}{*}{\begin{tabular}{|l|}
$\begin{array}{l}\text { Standardized } \\
\text { Coefficients }\end{array}$ \\
Beta \\
\end{tabular}} & \multirow[t]{2}{*}{$\mathrm{t}$} & \multirow[t]{2}{*}{ Sig. } \\
\hline & & $\mathrm{B}$ & Std. Error & & & \\
\hline \multirow[t]{2}{*}{1} & (Constant) & 26999,724 & 10200,126 & \multirow[b]{2}{*}{0,898} & 2,647 & 0,077 \\
\hline & $\begin{array}{l}\text { Planned } \\
\text { duration }\end{array}$ & 24,658 & 6,994 & & 3,526 & 0,039 \\
\hline \multicolumn{7}{|c|}{ Sector = Administrative buildings and economic infrastructures. } \\
\hline \multicolumn{7}{|c|}{ Dependent Variable: COST OVERRUN } \\
\hline
\end{tabular}

Table 6: Model summary (Education sector)

\begin{tabular}{|c|c|c|c|c|c|c|c|c|c|}
\hline \multicolumn{10}{|c|}{ Model Summarya, c } \\
\hline \multirow{2}{*}{$\begin{array}{l}\text { Mo } \\
\text { del }\end{array}$} & \multirow[t]{2}{*}{$\mathrm{R}$} & \multirow{2}{*}{$\begin{array}{l}\text { R } \\
\text { Squa } \\
\text { re }\end{array}$} & \multirow{2}{*}{$\begin{array}{l}\text { Adju } \\
\text { sted } \\
\text { R } \\
\text { Squa } \\
\text { re }\end{array}$} & \multirow{2}{*}{$\begin{array}{l}\text { Std. } \\
\text { Error of } \\
\text { the } \\
\text { Estimate }\end{array}$} & \multicolumn{5}{|c|}{ Change Statistics } \\
\hline & & & & & $\begin{array}{l}\text { R } \\
\text { Squar } \\
\text { e } \\
\text { Chang } \\
\text { e }\end{array}$ & $\begin{array}{l}\text { F } \\
\text { Chang } \\
\text { e }\end{array}$ & $\begin{array}{l}\mathrm{df} \\
1\end{array}$ & $\begin{array}{l}\mathrm{df} \\
2\end{array}$ & $\begin{array}{l}\text { Sig. F } \\
\text { Chan } \\
\text { ge }\end{array}$ \\
\hline 1 & $\begin{array}{l}0,79 \\
3 \mathrm{~b}\end{array}$ & 0,628 & $\begin{array}{l}0,53 \\
5\end{array}$ & $\begin{array}{l}234803, \\
91689\end{array}$ & 0,628 & 6,758 & 1 & 4 & 0,060 \\
\hline \multicolumn{10}{|c|}{ Sector = Education } \\
\hline Prec & ors: ( & istant) & $\mathrm{IEO}$ & UN & & & & & \\
\hline
\end{tabular}

Table 7: ANOVA (Education sector)

\begin{tabular}{|c|c|c|c|c|c|c|}
\hline \multicolumn{7}{|c|}{ ANOVAa,c } \\
\hline \multicolumn{2}{|c|}{ Model } & Sum of Squares & $\mathrm{df}$ & Mean Square & $\mathrm{F}$ & Sig. \\
\hline \multirow[t]{3}{*}{1} & Regression & $\begin{array}{l}372580621335,9 \\
33\end{array}$ & 1 & $\begin{array}{l}3725806213 \\
35,933\end{array}$ & \multirow[t]{3}{*}{6,758} & \multirow[t]{3}{*}{$0,060 \mathrm{c}$} \\
\hline & Residual & $\begin{array}{l}220531517547,4 \\
01\end{array}$ & 4 & $\begin{array}{l}5513287938 \\
6,850\end{array}$ & & \\
\hline & Total & $\begin{array}{l}593112138883,3 \\
34\end{array}$ & 5 & & & \\
\hline \multicolumn{7}{|c|}{ Sector $=$ Education } \\
\hline \multicolumn{7}{|c|}{ Predictors: (Constant), TIME OVERRUN } \\
\hline \multicolumn{7}{|c|}{ Dependent variable : COST OVERRUN } \\
\hline
\end{tabular}


Table 8: the coefficients of the line of regression (Education sector)

\begin{tabular}{|c|c|c|c|c|c|c|}
\hline \multicolumn{7}{|c|}{ Coefficientsa,b } \\
\hline \multirow{2}{*}{\multicolumn{2}{|c|}{ Model }} & \multicolumn{2}{|c|}{$\begin{array}{l}\text { Unstandardized } \\
\text { Coefficients }\end{array}$} & \multirow{2}{*}{\begin{tabular}{|l|}
$\begin{array}{l}\text { Standardized } \\
\text { Coefficients }\end{array}$ \\
Beta \\
\end{tabular}} & \multirow[t]{2}{*}{$\mathrm{t}$} & \multirow[t]{2}{*}{ Sig. } \\
\hline & & $\mathrm{B}$ & Std. Error & & & \\
\hline \multirow[t]{2}{*}{1} & (Constant) & 55326,607 & 172988,482 & \multirow[b]{2}{*}{0,793} & 0,320 & 0,765 \\
\hline & $\begin{array}{l}\text { Planned } \\
\text { duration }\end{array}$ & 828,803 & 318,821 & & 2,600 & 0,060 \\
\hline \multicolumn{7}{|c|}{ Sector = Education } \\
\hline \multicolumn{7}{|c|}{ Dependent Variable: COST OVERRUN } \\
\hline
\end{tabular}

\section{Conclusion}

"Delay considered as one of the most common problems causing a multitude negative effect on projects and its participating parties."(Gebrehiwet and Luo, 2017), among these effects are cost overruns. "When there is a delay in construction projects, they are either expedited or the scheduled time for the completion of project, is extended. The result is cost overrun in both the cases." (Saiful haq et al, 2014).

The objective of this study is to mesure the impact of schedule delay on cost overrun in Algerian construction project. Therefore, data from 11 public projects in the region of Constantine have been collected for the analysis.

The simple linear regression has been used to mesure the impact of delays on cost overruns, and the findings show that there is a strong relationship between cost and time overrun, and that delay has a positive impact on cost overrun.

Also, the results reveal that the developed model is appropriate for the prediction of cost overrun, and it can be used by practitionners in contruction projects as predictive mesure to reduce possible cost overrun.

\section{References}

[1] Salhi, R. (2018). Prediction of Delays in Construction Projects in Algeria. European Journal of Engineering and Formal Sciences, 1(1), 6-10.

[2] Sambasivan, M., \& Soon, Y. W. (2007). Causes and effects of delays in Malaysian construction industry. International Journal of project management, 25(5), 517-526.

[3] Aibinu, A. A., \& Jagboro, G. 0. (2002). The effects of construction delays on project delivery in Nigerian construction industry. International journal of project management, 20(8), 593-599.

[4] Gajare, Y., Attarde, P., \& Parbat, D. K.(2014). Assessment of Significant Causes And Effects Of Delays On The Projects Completion. International Journal of Modern Trends in Engineering and Research.

[5] Sun, M., \& Meng, X. (2009). Taxonomy for change causes and effects in construction projects. International journal of project management, 27(6), 560-572. 
[6] Salhi, R., Messaoudi, K., \& Boudemagh, S. S. (2018). Identification of Factors Causing Delays in Construction Projects in Algeria. European Journal of Engineering and Formal Sciences, 2(1), 6-11.

[7] Al-Momani, A. H. (2000). Construction delay: a quantitative analysis. International journal of project management, 18(1), 51-59.

[8] Gbahabo, P. T., \& Ajuwon, O. S. (2017). Effects of Project Cost Overruns and Schedule Delays in Sub-Saharan Africa. European Journal of Interdisciplinary Studies, 3(2), 46-59.

[9] Gebrehiwet, T., \& Luo, H. (2017). Analysis of delay impact on construction project based on RII and correlation coefficient: Empirical study. Procedia engineering, 196, 366-374.

[10] Haq, S., Rashid, Y., \& Aslam, M. S. (2014). Effects of delay in construction projects of Punjub-Pakistan: An emperical study. Journal of Basic and Applied Scientific Research, 4(4), 98-104. 